\title{
Natural Law and Integral Humanism by J. Maritain: Teaching Challenges Zuzana Svobodová
}

\begin{abstract}
The article examines (based on an analysis of texts of an important French thinker) the concept of natural law and humanism in order to offer inspiration to today's formation of man. This is an analysis of Maritain's work, especially in the field of political philosophy (Integral Humanism and the Crisis of Modern Times, Christianity and Democracy, Man and the State, The Peasant of the Garonne: An Old Layman Questions himself about the Present Time), philosophy of education (Education at the Crossroads, Philosophy and Education, Education and the Humanities, Moral and Spiritual Values in Education, The Crucial Problem of the Education of the Human Being, Pour une philosophie de l'éducation), and religious philosophy (The Range of Reason, Religion and Culture). A concrete example of the Human Rights Teaching Programme shows that Maritain's philosophy of education and his stimuli for education can be inspiring for current teachers and other workers in the helping professions who aspire to cultivate humanity, and not only for them. Jacques Maritain considered education to be an art, that is, an activity that is not an animal's training. The main goal of education, according to Maritain, is to bring man towards freedom through knowledge and wisdom, good will and love. The author of the paper questions the possible deeper theoretical foundations of integration in education, the role of the Christian-educator in contemporary society, and the possibilities and limits of human rights education. Based on the humanistic tradition (in the case of Maritain's work, it is inspired mainly by the work of Thomas Aquinas) and selected current educational documents, the presented text offers concrete examples of good practice and suggestions for social educators, educators, teachers, or parents, that is, for those who are involved in the process of education.
\end{abstract}

Keywords: Jacques Maritain, integral humanism, forms of humanism, natural law, human rights, humanity, culture, education

\section{Introduction}

What is the role of the Christian-educator in the world? Can the ideas of humanism be fruitful nowadays? What is the theoretical source of today's overused term 'integration'? What kind of 
view of the person stands behind the effort to integrate in schools, that is, where to take inspiration for a strong personal justification of a positive attitude towards school integration? Are we trying to fulfil the 'natural rights' of man by integration? How specifically can a contemporary teacher contribute to the development of a society that respects human rights as one of its core values? How deeply can contemporary education draw inspiration from the work of the thinker who created specific ideas for the education he personally saw in crisis - but more than half a century ago? The following text builds on these and other related issues seeking to show how these questions can be answered in the context of the work of an author who contributed to the formulation and interpretation of the Universal Declaration of Human Rights ${ }^{1}$ - a philosopher, educator, diplomat, and inspirer during the establishment of papal documents on social questions, ${ }^{2}$ Jacques Maritain.

Jacques Maritain centres bring a deeper view of Maritain's life and work, currently being mainly the Center at Notre Dame University in Indiana, US. ${ }^{3}$ Maritain's main ideas for education were published for the first time on the basis of lectures given by Maritain during World War II at Yale University within the Terry Lectures; they were published in the same year in which the lectures took place, in 1943, and were titled Education at the Crossroads (and by 1957 there had been nine editions). In the framework of the Jacques and Raïssa's Maritain work collection (published in French), texts about education were published in the seventh volume under the title Pour une philosophie de leducation. The four chapters originally included in Education at the Crossroads were extended by three more chapters - Maritain's texts about education which also emphasise not only the US but also the French educational and formational environment.

So far, only the basic works of Maritain have been published in Czech. The first (published in 1931) was the publication Vybrané stati filosofické (selected philosophical articles, published in English as Introduction to Philosophy), two years later Uméní a scholastika (Art and Scholasticism: With Other Essays), and in 1936 Náboženství a kultura (Religion and Culture). In 1947, Maritain's book Humanisme intégral was published under the title Křstanský humanismus (Christian Humanism), and in the same year another book was in the Slovak language Traja reformátori: Luther - Descartes - Rousseau (Three Reformers: Luther, Descartes, Rousseau). There were also radio sessions collected in the book Vánoce 1943 (Christmas 1943). In 1967, there was published a new translation of Maritain's Humanisme intégral, under the title Integrální humanismus (Integral Humanism) with the epilogue by Karel Vrána (he wrote it under the pseudonym Pavel Želivan). In Czech Catholic intellectual circles, the book became a cult primarily for its clear critique of Marxism. In 1976, a double issue of the exile magazine Study (46-47) was published as 'Maritainův sborník' ('Maritain's Proceedings') - and for the purposes of this article I would point out that Karel Skalický recalls (in his introductory text) also a seminar directly dealing with Maritain's Philosophy of Education, organised on $1^{\text {st }}-4^{\text {th }}$ October 1975 in Brescia, Italy (the

1 Cf. Jacques MARITAIN, Introduction, in: United Nations Educational Scientific and Cultural Organization, Human Rights: Comments and Interpretations, Paris: UNESCO, 25. 6. 1948, pp. I-IX. Available at: http://unesdoc.unesco.org/images/0015/001550/155042eb.pdf, cited $25^{\text {th }}$ April 2017. Cf. also Philosophical Examination of Human Rights, ibid., pp. 59-63.

2 The encyclical letter of Paul VI Populorum progressio, issued on $26^{\text {th }}$ March 1967, explicitly refers to J. Maritain's work (in particular in Articles 20 and 42, and the influence of his work L'humanisme intégral can also be seen in Articles 16n, 26, 34, 39) - cf. Jacques MARITAIN, Křestanský humanismus, translated by Vojtěch Gaja, Prague: Universum, 1947, pp. 97-104, 283 and Populorum progressio, 16-42.

3 In Europe, for example, there were established the Jacques and Raïssa's Maritain Center for Studies (Cercle détudes Jacques et Raïssa Maritain) in Kolbsheim, France, and Jacques Maritain's International Institute (L'Istituto Internazionale Jacques Maritain) in Italy. In the Czech Republic, Czech Jacques Maritain Society (Česká společnost Jacquesa Maritaina) was founded in 1993. The work of J. Maritain can also be found among the topics of the research centre at the Faculty of Theology at the University of South Bohemia, namely, among the topics of the Research Group for the Study of Post-Medieval Scholastics. Presentation of the US Center is available at: https:// maritain.nd.edu/, cited on $5^{\text {th }}$ May 2017. 
organiser was the L'Istituto Internazionale Jacques Maritain and Milan Catholic University). At the same time, an Italian translation of The Education of Man, The Educational Philosophy of Jacques Maritain (Leducazione al bivio) was published. ${ }^{4}$

Three and a half years after the Velvet Revolution, Česká společnost Jacquesa Maritaina (the Czech Jacques Maritain Society), as a branch of the Jacques Maritain International Institute, was founded. Its founder, Karel Šprunk, continues to be the main translator of the work of J. Maritain. In the Czech language, several minor works of Maritain have been published. These are Láska a prátelsví, 2005 (Love and Friendship), Život $z$ modlitby, 2005 (A Faith to Live by), Víra v člověka, 2008 (a compilation of three works: Truth and Human Fellowship, La signification de l'athéisme contemporain, and Une foi quoi l'on vit?), but above all Maritain's work of political philosophy Člověk a stát, 2007 (Man and the State), Sedm lekcí o jsoucnu a o prvních principech spekulativního rozumu, 2009 (A preface to metaphysics; seven lectures on being), Odpovědnost umèlce, 2011 (The Responsibility of the Artist), O filosofii dějin, 2014 (On the Philosophy of History). In 2006, the second issue of the journal Salve was devoted to the thinking of J. Maritain, and there were also printed for the first time some of Maritain's texts translated into Czech.

The Czech book edition of the main ideas of Maritain from the field of philosophy of education (summarised in the publications Pour une philosophie de l'education, Education at the Crossroads, The Education of Man) has not been published yet. ${ }^{5}$ Meanwhile, those who are interested in Maritain's philosophy of education in the Czech language can find relevant information, in particular, in the third part of the fifth chapter of the book Man and the State, which is devoted to formation to support the democratic charter. More generally on the topic of Christians' responsibility in society, one can find inspiration in Integral Humanism. Maritain's Proceedings (prepared by the Christian Academy in Rome) are now available online in electronic form. The first translated text in those proceedings regards what one needs in order to live a renewed, heroic Christian life - to live the life of a Christian turned towards Christ's Cross and God's grace. There is presented a treatise on the means of self-formation towards integral humanity. In the history of Czech pedagogical thinking, J. Maritain is mentioned only sporadically, which is probably due to the fact that understanding Maritain's concept of education requires at least a basic understanding of Christianity, the biblical concept of man, the meaning of Christ's sacrifice and God's mercy, or the understanding of the theory of human rights in its roots, long before the time of the Enlightenment.

Therefore, if the educator should benefit from Jacques Maritain's work on the philosophy of education, I think it is important to outline at least briefly the basic concept of natural law, the core of human rights theory, in the work of Jacques Maritain.

\section{J. Maritain on Natural Law}

The idea of natural law is the inheritance of classical, ancient thinking. According to Maritain, Antigone is the eternal heroine of natural law, of an unwritten law. The ancient Greek playwright

Jacques MARITAIN, L’educazione al bivio, Introduzione di A. Agazzi, 18 ed., La Scuola, Brescia, 1975.

According to information in the French edition of the works of Jacques and Raissa Maritain (the seventh volume bibliographical appendix, after the part devoted to Pour une philosophie de l'éducation), there is a statement saying that various parts or translations of this work also appeared in Czechoslovakia. For example, in the samizdat magazine Study No. 6, 1960, there was Maritain's text The Preconscious Life of the Intellect (Podvědomý život intelektu), and, especially, in 1976, there was the double issue 46-47 published as 'Maritainův sborník' ('Maritain's Proceedings'). Most probably, the following French note refers to those Czech texts - cf. Jacques MARITAIN, Pour une philosophie de léducation. In Jacques et Raïssa Maritain OEuvres complètes, Fribourg Suisse/Paris (Éditions universitaires/Èditions Saint-Paul) 1982-2007, CEC VII: CEuvres de Jacques Maritain 1939-1943, p. 1360 and Studie 46-47, Maritainův sborník, Rome: Křestanská akademie, 1976. 
Sophocles is for Maritain the first among the personalities who have embraced the idea of natural law and thus one must start with him. Besides the great poets, Maritain mentions the great ethicists of ancient times, the Stoics, Cicero, the Apostle Paul, the Church Fathers, Augustine, Thomas Aquinas, Francisco de Vitoria, Suarez, Hugo Grotius, pointing out that later in 18th century philosophy the idea of natural law was more or less deformed. Maritain certainly opposes the widespread view that natural law is the invention of the American or French Revolution. ${ }^{6}$

The idea of natural law is based on the belief that there is human nature that is the same in all people. Such nature includes the idea that man is gifted with rational and intellectual insight, which leads one to an awareness of his behaviour or activity, and hence to the power by which one can influence one's own actions and pursue one's own goals. Maritain often recalls the ancient philosophical idea that the goal of man is to be a seer. ${ }^{7}$ Thanks to human nature, there is an arrangement (internal order) or disposition that human reason can discover, and according to which the human will then has to act in order to be able to adapt itself to the desired goals of the human being. Unwritten law, or natural law, is precisely this internal disposition which can be understood and seen by rational and intellectual insight, the mind. ${ }^{8}$

Natural law and knowledge of natural law is not the same. A person who has not yet been able to know this law (or because of an ailment no longer has the opportunity to know this law) is not accountable to the law - and, on the contrary, since the law is accessible to him, through rational insight, he is legally responsible even if he does not assign himself to it. The idea of natural law derives from this (unwritten and never completely written or recorded) natural law. And any human being (even one who does not have knowledge of natural law) has the natural right to protect his human nature. This law is 'inscribed in one's heart' truthfully and deeply (it is difficult to look into one's own 'heart' and impossible for one to look into the heart of another). One only knows natural law to a certain degree as it is impossible to 'rewrite' it from one's 'heart' to one's 'head' - Pietists have also used these metaphors to express their view saying that dynamism (which is more connected with one's will, that is, with the 'heart') is a greater depth, the very essence of the human being. Therefore, it was their aim to move Christianity (the way of life coming from Christ's teaching) 'from one's head to one's heart.' ${ }^{9}$ Growth of natural law is associated with the development of moral consciousness Maritain favoured the research done by Jean Piaget very much, and even today's educators can be given the recommendation to familiarise themselves with the results of Piaget's students' research. ${ }^{10}$ If Maritain speaks of culture as the intellectual development of a human being in all his completeness, ${ }^{11}$ the recognition of natural law is considered to be the cultivation, or enculturing of the person. Efforts of human spirit and freedom are joining the potential of nature. In this sense, culture is natural to man. ${ }^{12}$ 'Man, natural completely and earnestly, is not a raw existence, nor a fallow land, but a man of virtue, a human ground educated by common sense, a man created by an inner culture of intellectual and moral virtues. Only such a person has consistency, he is a personality.' ${ }^{\prime 3}$

6 Cf. Jacques MARITAIN, The Rights of Man and Natural Law, London: Geoffrey Bles, 1958, p. 34. To be able to analyse the secularisation of natural law, cf. Tomáš MACHULA, The Way to the Secularisation of the Natural Law, Filosofický časopis, Special Issue 2016, pp. 41-58.

7 Cf. Jacques MARITAIN, The Education of Man: The Educational Philosophy of Jacques Maritain, ed. Donald Gallagher, Idella Gallagher, Notre Dame: University of Notre Dame Press, Doubleday \& Co., 1967, p. 61.

8 Cf. MARITAIN, The Rights of Man and Natural Law, p. 35.

9 Cf. Zuzana SVOBODOVÁ, Pohnutky Kristova svědka: II. Jan Amos Komenský, Studia Comeniana et historica, XLVI (2016), nos. 95-96, especially note no. 69 , p. 128.

10 Cf. MARITAIN, The Education of Man, pp. 53, 190; cf. also Raïssa MARITAIN, La Conscience Morale et l'Etat de Nature, New York, 1942. Lawrence Kohlberg’s research is particularly useful, cf. Jolana POLÁKOVÁ, Morální vývoj osobnosti, Teologické texty 3/1994, pp. 104-105.

11 Cf. Jacques MARITAIN, Náboženství a kultura, Brno: Moravan, 1936, p. 8.

12 Cf. ibid.

13 Ibid., p. 11. 
In this way Jacques Maritain expresses his characteristics of man in relation to his nature - and in such matter, he is a disciple of Aristotle, ${ }^{14}$ and also Thomas Aquinas. ${ }^{15}$

Jacques Maritain realised that people of different faiths, different traditions of thought would not be able to agree on the reason why fundamental human rights should apply. He had the hope, however, that people from different cultures would be able to agree on the basic definition of human rights, that is, that they would be able to agree with the order of fundamental values, with the practical concept of man and life, with the 'philosophy of life' that would be a practical manifestation of civilised living. ${ }^{16}$ In the summer of 1948, he himself was aware of the fact that it was necessary to start with the necessary changes worldwide. ${ }^{17} \mathrm{He}$ personally offered inspiration, for example, through his concept of integral humanism and his philosophy of education.

\section{Integral, Christian Humanism}

Under the title Integral Humanism lectures were published by Jacques Maritain which were held at the Santander Summer University in $1934 .{ }^{18}$ What Jacques Maritain offers as a way out of the (in his time) contemporary crisis ${ }^{19}$ is a new concept of humanism that would be theocentric, Christian, heroic, progressive, integral, complete, humanism of incarnation. ${ }^{20}$ Education, at a time when Christian civilization can no longer be naïve, ${ }^{21}$ should (in the spirit of this new humanism ${ }^{22}$ ) lead to the freedom of human beings, to the freedom of $\operatorname{man}^{23}$ as an individuality and as a person. The individuality is (in Maritain's view) understood as a physical basis for a person. According to Maritain, contemporary education is mistaken specifically in the perspective of man and in the development of his individual and personality character. ${ }^{24}$

According to Maritain, integral humanism will require radical changes in culture, even substantive changes:

And this transformation requires not only the establishment of new social structures and the new system of social life rising after capitalism, but also an increase of forces of faith, understanding and love,

14 Cf., for example, ARISTOTELÉS, Magna moralia, Prague: Petr Rezek, 2005, 1184b, 26-32.

15 The question 'Whether a man can naturally achieve blessedness?' and its solution can be found, for example, in Thomas Aquinas, Summa Theological, Part II, Episode I, Q. 5, Art. 5 (Cf. 33709 Ia-IIae q. 5 a. 5). Cf. Tomáš AKVINSKÝ, Summa teologická, translated from the original Latin text Sancti Thomae Aquinatis, SUMMA THEOLOGIAE by Emilián Soukup, published in Olomouc 1937-1940, the original translation was corrected according to the additional Olomouc correcting pages and adapted for current readers by Tomás Bahounek, the referred text being available in Czech at: http://areopag.sk/thomas/SummaTheologica-II-I.html, in Latin available at: http://www.corpusthomisticum.org/sth2001.html \#33709, cited 14 ${ }^{\text {th }}$ May 2017.

16 Cf. MARITAIN, Introduction, p. I, IX.

17 Ibid., p. IX.

18 The first lectures came out in Spanish under a different name and Maritain himself used the expression 'integral humanism', for example, in an article published in 1939: Jacques MARITAIN, Integral Humanism and the Crisis of Modern Times, The Review of Politics, vol. 1, 1939, pp. 1-17 (on-line), available at: www.jstor.org/stable/1403915, cited 14 ${ }^{\text {th }}$ June 2017. In Czech, Maritain's lectures from the Summer University of 1937 first appeared under the title Christian Humanism, cf. Jacques MARITAIN, Krestanský humanismus, translated by Vojtěch Gaja, Prague: Universum, 1947. In the new translation twenty years later, the lectures came out under the title Integral Humanism, cf. Jacques MARITAIN, Integrální humanismus, translated by Josef Petr, Rome: Křestanská akademie, 1967.

19 Literally, he talks about the 'tragedy of humanism' - cf. MARITAIN, Křestanský humanismus, p19.

20 Cf. MARITAIN, Křestanský humanismus, pp. 80-82. Cf. Jacques MARITAIN, Christianity and Democracy, New York: Charles Scribner's Sons, 1945, pp. 92-98. Cf. Jacques MARITAIN, The Range of Reason, available at: http://maritain.nd.edu/jmc/etext/range07. htm\#p92, cited $27^{\text {th }}$ June 2017.

21 Cf. MARITAIN, Křestanský humanismus, p. 84.

22 Cf. MARITAIN, Křstanský humanismus, pp 81ff.

23 Cf. MARITAIN, Křestanský humanismus, pp. 84-86.

24 Cf. MARITAIN, Education at the Crossroads, pp. 7-10, 33-35: there are seven mistakes in the concepts of human education according to Maritain, cf. pp. 2-24 (overlooking of goals, bad ideas associated with goals, pragmatism, sociologism, intellectualism, voluntarism, the belief that everything can be learned). Man (individuality and person at the same time) is different from all other living creatures; his education cannot be considered as dressage: 'education is not animal training. The education of man is a human awakening' (p. 9, cf. p. 6). 
coming from the inner springs of the soul. It requires progress in discovering the world of spiritual facts. Only under this condition will one really be able to advance further into the depths of his nature without having to change or deform it. ${ }^{25}$

Here is an essential view of the nature of man, which is the basis of the whole concept of Maritain's integral humanism. Maritain believes that, through self-cultivation and with the help of appropriate education, ${ }^{26}$ one can descend into these essential depths of his own nature, to the inner springs of the soul.

Jacques Maritain, by his works on the need for a new concept of humanism as an integral humanism, has also contributed to the development of the social teaching of the Church. The encyclical letter Caritas in veritate (Charity in Truth) which has the subtitle On Integral Human Development in Charity and Truth and concerns the social teaching of the Church has already been dealt with on the pages of this magazine (note: Caritas et veritas). ${ }^{27}$ This pope had already written about Christian humanism in the 1960 s. $^{28}$ Pope Francis used the term 'integral' directly in connection with ecology, and indirectly also with humanism. ${ }^{29} \mathrm{He}$ also expresses, in his encyclical letter Laudato si', the need for ecological education that will contribute to the integral conversion of the human person and thus cultivate all human relationships. ${ }^{30}$

Jacques Maritain combined the term integral with the term advanced $^{31}$ in the sense (as previously indicated) of personal growth towards profound spiritual resources in which one recognises the Truth, a believer sees his Creator and his principle of love, mercy, understanding, acceptance. It can be said that Maritain interprets the biblical concept of man and his task in such a way. The principle of humanity was seen in loving affection also by John Amos Comenius who (three centuries earlier and also at a time of social crisis) had worked on expressing the basis of humanity. ${ }^{32}$ Maritain proposes (as the way out of the crisis) a formation leading to the transformation of man which would actually be a reversal to the springs of the spirit and, at the same time, would be a strengthening and nourishing of the spiritual life. Such a transformation would also affect social institutions. ${ }^{33} \mathrm{He}$ thinks about integral upbringing for integral humanism. ${ }^{34} \mathrm{He}$ personally collaborated on major projects of his time which he considered to be hopeful in the spirit of this integral humanism; he participated, for example, in the formulation (and also the interpretation) of the Universal Declaration of Human Rights. ${ }^{35}$

25 MARITAIN, Křestanský humanismus, p. 99.

26 Cf. MARITAIN, The Education of Man, pp. 123-124.

27 Jindřich ŠRAJER, Fenomén migrace z pohledu ideje rozvoje společného domova obsažené v sociálním učení církve, zvláště ve vyjádřeních papežů Benedikta XVI. a Františka, Caritas et Veritas 2/2016, pp. 118-120.

28 Cf. Karel RAHNER, Christlicher Humanismus, in: Schriften zur Theologie, vol. 8, Einsiedeln 1967, pp. $239-259$.

29 Laudato si', 141, 181.

30 Laudato si', the term 'integral' is found in the following encyclical paragraphs: 10, 11, 13, 18, 46, 50, 60, 62, 109, 124, 137, 139 (here the pope explains that 'integral solutions' should include the interaction of natural systems between themselves and, at the same time, between them and social systems), 141 (here is the urgent need for humanism to fulfil an integral and integrative vision), 157, 159, 185, 197, 213 (here the family is referred to as the 'integral formation'), 218 (the model of 'integral conversion of the human person' is, according to this text, Francis of Assisi), 225, 230 (a concrete friendly, loving affection for another, manifested, for example, by gesture, is also a part of 'integral ecology').

31 Cf. MARITAIN, Krestanský humanismus, pp. 80-81.

32 Cf. Jan Amos KOMENSKÝ, Orbis sensualium pictus, Prague: Levné knihy KMa, 2001, CXV, p. 248. Cf. Jan Amos KOMENSKÝ, Orbis sensualium pictus, in: Dílo Jana Amose Komenského. Opera omnia, vol. 17. Prague: Academia, 1970, CXV, p. 216. J. Maritain refers directly to Comenius: MARITAIN, Education at the Crossroads, p. 60, the note at the end of the page.

33 Cf. MARITAIN, Pour une philosophie de l'éducation, pp. 936, 944, 947, 952, etc. MARITAIN, Education at the Crossroads, the main goal of education is described by Maritain as follows: 'The prime goal of education is the conquest of internal and spiritual freedom to be achieved by the individual person, or, in other words, his liberation through knowledge and wisdom, good will, and love' (p. 11).

34 Cf. MARITAIN, Education at the Crossroads, p. 88.

35 Cf. my first footnote. 


\section{Suggestions for Teaching Human Rights Topics}

Contributing to the fulfilment of human rights is one of the main goals of education, as represented by Education 2030, ${ }^{36}$ the strategical documents. Also, the approaches to education are still not fair and, according to the current data, this goal is still impossible to reach worldwide. ${ }^{37}$ The largest international organisations dealing with education focus not only on monitoring the current state of affairs, ${ }^{38}$ but also on defining common values in the field of education. ${ }^{39}$ In addition to appealing to the governments of the responsible countries, they offer support to individual states for quality education. ${ }^{40}$ Specifically, for human rights education, there are, for example, materials on global civic education issued by $\mathrm{UNESCO}^{41}$, or a human rights education and training website. ${ }^{42}$ The United Nations has a world human rights education programme where its third phase is currently in progress. ${ }^{43}$ For the purposes of human rights education, films have been made. ${ }^{44}$ The Council of Europe has published a charter for education in this area. ${ }^{45}$ Also, the international conferences are held to promote good practice in human rights education. ${ }^{46} \mathrm{New}$ publications are published ${ }^{47}$ new exhibitions and up to date recommendations are presented. ${ }^{48}$ The European Union has established an interdepartmental centre for excellence in human rights education (The European Inter-University Centre for Human Rights and Democratisation). ${ }^{49}$

36 Cf. World Education Forum 2015, Education 2030 Incheon Declaration: Towards inclusive and equitable quality education and lifelong learning for all, ED-2016/WS/28, 2016, in the text it is further cited as: SDG4-Education 2030, available at: http://unesdoc.unesco.org/ images/0024/002456/245656E.pdf, cited 20 ${ }^{\text {th }}$ May 2017, Article 61.

37 Cf. UNESCO, Education 2030: Equity and quality with a lifelong learning perspective, Insights from the EFA Global Monitoring Report's World Inequality Database on Education (WIDE), ED/EFA/MRT/2015/WS/02, May 2015, available at: http://unesdoc.unesco. org/images/0023/002330/233029e.pdf, cited 20 th May 2017, pp. 2-9.

38 Cf. ibid.

39 Cf. SDG4-Education 2030 cf. also UNESCO, Outcome document of the Technical Consultation on Global Citizenship Education: Global Citizenship Education - An Emerging Perspective, 2013, available at: http://unesdoc.unesco.org/images/0022/002241/224115E.pdf, cited $20^{\text {th }}$ May 2017.

40 Cf. SDG4-Education 2030, cf. also UNESCO, Roadmap for Implementing the Global Action Programme on Education for Sustainable Development, 2014, available at: http://unesdoc.unesco.org/images/0023/002305/230514e.pdf, cited 20 $0^{\text {th }}$ May 2017.

41 Cf. UNESCO, The ABCs of Global Citizenship Education, available at: http://unesdoc.unesco.org/images/0024/002482/248232e.pdf, cited $20^{\text {th }}$ May 2017; for more information cf. UNESCO, Global Citizenship Education, available at: http://en.unesco.org/gced, cited 20 ${ }^{\text {th }}$ May 2017.

42 Cf. UNESCO, Human Rights Education, available at: http://www.unesco.org/new/en/education/themes/leading-the-internationalagenda/human-rights-education/, cited $20^{\text {th }}$ May 2017; cf. also HREA, The global human rights education and training centre, available at: http://www.hrea.org/, cited 20 $0^{\text {th }}$ May 2017.

43 OHCHR, World Programme for Human Rights Education, available at: http://www.ohchr.org/EN/Issues/Education/Training/Pages/ Programme.aspx, cited $20^{\text {th }}$ May 2017.

44 Cf. a film HREA, SGI, OHCHR, A Path to Dignity: The Power of Human Rights Education, available at: http://www.path-to-dignity. org/, cited 20 th May 2017. Furthermore, for example, there are films on special pages of EDC/HRE subjects: Council of Europe, Education for Democratic Citizenship and Human Rights Education (EDC/HRE), available at: http://pjp-eu.coe.int/en/web/charter-edc-hre-pilotprojects/comics-competition, cited $26^{\text {th }}$ June 2017.

45 Council of Europe, Charter on Education for Democratic Citizenship and Human Rights Education, October 2010, available at: http://www. coe.int/en/web/edc/charter-on-education-for-democratic-citizenship-and-human-rights-education, https://rm.coe.int/16803034e3, cited $26^{\text {th }}$ June 2017.

46 At the time of this text being finalised, a conference (organised under the Czech presidency of the Committee of Ministers of the Council of Europe) was held in Strasbourg under the name Learning to Live Together: A Shared Commitment to Democracy. Conference on the Future of Citizenship and Human Rights Education in Europe. Palais de l'Europe, Strasbourg, $20^{\text {th }}-22^{\text {nd }}$ June 2017. Organised in the framework of the Czech Chairmanship of the Committee of Ministers of the Council of Europe (May - November 2017), available at: http://www.coe.int/en/web/edc/conference, http://www.coe.int/en/web/edc/report-on-the-state-of-citizenship-and-human-rights-ineurope, cited $26^{\text {th }}$ June 2017.

47 The last publication came out in June 2017: Council of Europe, Learning to Live Together. Council of Europe Report on the state of citizenship and human rights education in Europe, available at: https://rm.coe.int/the-state-of-citizenship-in-europe-e-publication/168072b3cd, cited $26^{\text {th }}$ June 2017.

48 Council of Europe, Charter for All, available at: http://www.coe.int/en/web/edc/charter-for-all, cited 26 ${ }^{\text {th }}$ June 2017. Here, one can recall Maritain's liberal education for all (often thought out by him) - cf., for example, MARITAIN, The Education of Man, pp. 69-75; one can find universal liberal education, cf., for example MARITAIN, Education at the Crossroads, pp. 64-65.

49 EU, The European Inter-University Centre for Human Rights and Democratisation (EIUC), available at: https://eiuc.org/about-us/ 
A teacher or educator who wants to incorporate human rights issues into his educational and upbringing activities certainly does not have a lack of material. It is up to him to choose the best for the children, youth, or adults he is entrusted with. I think it is appropriate for him to think very well, for example, about the appropriate use of freely available didactic materials for human rights education. There are Compasito ${ }^{50}$ (for children) and Compass $^{51}$ (for older children and youth) and others are accessible. Specific examples of good practice in human rights education include syllabuses for non-confessional ethics elaborated at the European School (Schola Europaea). ${ }^{52}$ By comparing syllabuses for education and training in the field of ethics in primary and secondary education in the Federal Republic of Germany and the United Kingdom of Great Britain and Northern Ireland, it has become clear that pupils are led to the recognition and reflection of human rights at an early age (that is, when they are eight years old). ${ }^{53}$

For those who want to talk about human rights (as educators or teachers), it is true that they should have the human rights idea reasonably proven for themselves. As already stated, it seems that the consensus in human rights justification among people of all cultures and traditions of thought cannot be found. Still, a teacher or educator who wants to make sure that human rights are truly understood by his students (that is, children or adults assigned to him) should be an example of a person who has gained a well-founded understanding of human rights. ${ }^{54}$

Despite the fact that, during the educational process, for educators (according to Maritain) awareness of the goal is the key aspect and the methods are not of primary importance, it is necessary for every educator and teacher (who looks for ways to reach human rights understanding) not to stay with one or only a few methods. ${ }^{55}$ When Jacques Maritain was considering the introduction of a democratic charter in schools, he wrote: 'The goal of school and the state is unity - unity in the joint adoption of the democratic charter. Although if one wants to reach this practical unity, there must be a healthy plurality in the means. If one wants the effective teaching of a democratic charter, the internal differentiation must find its own place in the structure of the educational system. ${ }^{56}$ Therefore, even though the democratic school and the state should work together in the process of the adoption of the human rights ideas by their pupils and citizens, they should allow for a pluralist structure in their organisation: 'In my opinion, the plurality that seems to be desirable for public schools should not touch the study program. It should be present in different inspirations, and in their perspective, the joint program would be realized ... ${ }^{37}$ Given the fact that human rights education and upbringing is about practice in the field of ethics (that is, practical philosophy), it is appropriate to point out the various possibilities of how people find

overview.html, cited $26^{\text {th }}$ June 2017.

50 Council of Europe, Compasito. Manual on human rights education for children. Budapest: Directorate of Youth and Sport of the Council of Europe, $2^{\text {nd }}$ ed., January 2009, available at: http://www.eycb.coe.int/compasito/chapter_0/0_impr.html, cited $26^{\text {th }}$ June 2017.

51 Council of Europe, Compass: Manual for Human Rights Education with Young People, available at: http://www.coe.int/en/web/compass, cited $26^{\text {th }}$ June 2017.

52 Schola Europaea, available at: https://www.eursc.eu/Syllabuses/Forms/Syllabuses.aspx, specifically, it is about new syllabuses for nonconfessional ethics in the English version: https://www.eursc.eu/Syllabuses/2016-01-D-32-en-3.pdf, p. 4, cited 27 June 2017. For the detailed analysis of the syllabuses of the European Schools cf. Zuzana SVOBODOVÁ, Petr JANDEJSEK, Michael MARTINEK and René MILFAIT, Důstojně a radostně: Př́spěvek k lidskoprávnímu, občanskému a etickému vzdělávání, Středokluky: Zdeněk Susa, 2012, pp. 132-137; cf. Zuzana SVOBODOVÁ, Výuka etiky na školách, Universum. Revue České krestanské akademie 3/2011, pp. 36-37; cf. Zuzana SVOBODOVÁ (ed.), K etické výchově, Prague: Karez, 2011, pp. 31-32; cf. Zuzana SVOBODOVÁ, Etická výchova jako cesta z omezené každodennosti, Paideia: Philosophical e-journal of Charles University 1/2011, pp. 2-4.

53 Cf. René MILFAIT, Zuzana SVOBODOVÁ, Vývoj a stav etického vzdělávání a teologickoetická reiterace lidských práv: příspěvek k etickému a lidskoprávnímu vzdělávání a k interkulturnímu porozumění hodnotám, Prague: Národohospodářský ústav Josefa Hlávky, 2017 , p. 25.

54 Cf. Jacques MARITAIN, Člověk a stát, Prague: Triáda, 2007, p. 109.

55 MARITAIN, The Education of Man, pp. 71, 94. Cf. MARITAIN, Pour une philosophie de l'éducation, p. 924.

56 MARITAIN, Člověk a stát, p. 109.

57 Ibid., p. 110. 
understanding for the great, good, and beautiful values of life. ${ }^{58}$ How the plurality of traditions and methods as part of human rights education is treated in the Federal Republic of Germany and the United Kingdom of Great Britain and Northern Ireland, I have shown elsewhere. ${ }^{59}$ I only emphasise the fact that the variety of resources that pupils and students encounter in such a learning process can help them better understand the positive value of pluralism, diversity among people, peoples, cultures. It is precisely due to the fact that we are different that we can learn something really new from each other. As Emmanuel Lévinas ${ }^{60}$ reminds us, we should not be limited by ourselves. He was also, as was J. Maritain, a pupil of H. Bergson.

On the other hand, according to Jacques Maritain's wife, Raïssa Maritain, there is one single fact that the educator or teacher should not forget to convey - the testimony that every human life is a gift which is loved, endowed with love, and designed for love. There is the law, and a good value is a just law. Love, though, is above the law. If we, as educators, spoke only about justice, law, and rights, we would forget the core, the most important thing. Given the varied palette of Jacques Maritain's life activities and work, and given that his lifelong memories end with the text of his wife pointing out the importance of the testimony of God who is love, I consider Jacques Maritain's texts about education very inspiring for educators and teachers in the $21^{\text {st }}$ century. These texts, in addition to the essential values of integral humanism, point out the great mistakes in education which were seen by Maritain more than half a century ago. The mistakes seen by him in the past are being repeated in the practice of education today, and it is not clear if these mistakes are made consciously - that is, if those who (according to Maritain's opinion) choose bad educational concepts ${ }^{61}$ at least know the roots of the concepts, which concepts of man and humanity are natural for them, and with which values, attitudes, and concepts of life they really want to support a person. Jacques Maritain criticised seven concepts which I still consider to be survivors in today's state education. Just as human rights are an idea, Maritain's proposals for integral education leading to integral humanity remain an idea that perhaps only a few educators and teachers in the Czech Republic are trying to fulfil. In a country that has been learning to live in freedom for more than thirty years, and whose institutions consider themselves to be democratic, we should no longer regard such issues as a 'consequence of the past regime'.

\section{Conclusion}

Jacques Maritain devoted a significant part of his life to thinking about the basics of education. Apparently, he was trying to be a man who would react to contemporary social events and would try to positively influence them. In education, he saw an exceptional opportunity to contribute to the humanity of man. He worked very actively on this matter and in his actions he was not alone. His companion was his wife Raïssa (with whom he accepted baptism into the Catholic Church and tried to live the exemplary life of an active Christian in society). Their energy devoted to this work was also drawn from the treasures of metaphysics. They devoted themselves to the studies of the work of Thomas Aquinas. Raïssa, for example, wrote a book for children about Thomas Aquinas. ${ }^{62}$

58 Cf. MARITAIN, The Range of Reason, available at: http://maritain.nd.edu/jmc/etext/range13.htm\#p179, cited $27^{\text {th }}$ June 2017.

59 Cf. MILFAIT, SVOBODOVÁ, Vývoj a stav etického vzdělávání ..., pp. 20-33, 36-39.

60 Cf. Emmanuel LÉVINAS, Čas a jiné/Le temps et l'autre, Prague: Dauphin, 1997, pp. 18n: 'encombrement du Moi par le Soi-même', cf. Emmanuel LÉVINAS, Totalita a nekonečno: (esej o exterioritě), Prague: OIKOYMENH, 1997, pp. 240, 242 - here the translators have chosen the Czech expressions 'zaplněný' (filled), 'zahlcený' (overwhelmed) to translate the French word 'encombrement'. Cf. Zuzana SVOBODOVÁ, Čas: Lidská otázka po původu a smyslu, Paideia: Philosophical E-journal of Charles University 1/2013, p. 11.

61 Cf., in this article, footnote 24.

62 Cf. Raïssa MARITAIN, Saint Thomas Aquinas: For Children and the Childlike, [rev. ed.], Manchester, N.H.: Sophia Institute Press, 2009, 
They were both convinced that it is now necessary to expand the narrow concept of man and, for that reason, they offered different possibilities in their written works (in both poetic and scholarly ones). When Jacques Maritain wrote the book 'The Peasant of the Garonne' immediately after the Second Vatican Council, he finished it with the text of his wife 'The True Face of God or Love and the Law' Jacques and Raïssa Maritain thus end their work with the testimony of God who is love that stands above the law. The work is about the love that creates trust, the freedom of the spirit without love one is not free so love must be presented and lived by the educator if he really wants to raise a person towards his purpose. ${ }^{63}$

The concept of natural law was reflected by J. Maritain at a time when natural law theory was not in the viewfinder of theoreticians, ${ }^{64}$ even though its results were often used and promulgated in the legal environment of its time. It was the next period which came with a certain renaissance of natural law theory. In the same way, another of Maritain's concepts, 'integral humanism' is resurrected beyond the limits of purely professional circles in contemporary times. Several concrete examples of contemporary didactic materials for teaching human rights topics show that Maritain's hope put into the teaching of the democratic charter was encouraging, and the work of Jacques and Raïssa Maritain can still be inspiring, not just for current teachers and other workers in the helping professions. Let us wish for the educators' courage and power to penetrate the critical texts of Jacques Maritain, revealing the roots of the crisis in education and society.

\section{Contact}

\section{PhDr. Bc. Zuzana Svobodová, Ph.D.}

University of South Bohemia in České Budějovice

Faculty of Theology, Department of Pedagogy

Kněžská 8, 37001 České Budějovice

svobodz@tf.jcu.cz

available at: https://play.google.com/store/books/details?id=Cc2hAQAAQBAJ\&source=ge-web-app, cited $26^{\text {th }}$ June 2017.

63 Cf. Jacques MARITAIN, The Peasant of the Garonne: An Old Layman Questions Himself about the Present Time, New York: Holt, Rinehart and Winston, 1968, p. 260.

64 Cf. Stanislav SOUSEDÍK, Svoboda a lidská práva, Prague: Vyšehrad 2010, p. 127. 